\title{
BC refutes Charter challenge of medicare
}

I t was the British Columbia government's turn Sept. 12 to rebut a Charter challenge barring doctors from operating both inside and outside the public health care system. However, anyone who came to the BC Supreme Court expecting an impassioned defence of medicare was disappointed. Instead, lawyer Jonathan Penner attacked the legal underpinnings of the case filed by Cambie Surgeries Corp., which operates a Vancouver private clinic, and its co-plaintiffs.

Penner's argument addressed core questions in the closely watched case: Does the law infringe doctors' freedom to provide and patients' right to receive timely medical care and, if it does, are those restrictions reasonable under the Canadian Charter of Rights and Freedoms?

The strains on the public system, such as waiting lists to see specialists and for surgeries, are "indisputable facts," Penner told Justice John Steeves.

But the remedy proposed by the plaintiffs - a hybrid system where doctors can deliver private and medicare services and patients can buy insurance for services already covered by medicare - will not solve the problem. In fact, said Penner, it could make things worse by disrupting the public system and diverting resources from it.

Penner warned that if the Cambie plaintiffs win their challenge, the implications will extend outside British Columbia. Other provinces have similar restrictions on physician practice and private insurance that, like $\mathrm{BC}$, are tied to federal transfer payments under the Canada Health Act.

The trial opened Sept. 6 when Peter Gall, acting for Cambie, an affiliated clinic and several patients, argued BC's Medicare Protection Act handcuffed both doctors and those seeking timely care.

The law prevents physicians from operating both inside and outside of the provincial Medical Services Plan. The restriction on so-called dual or

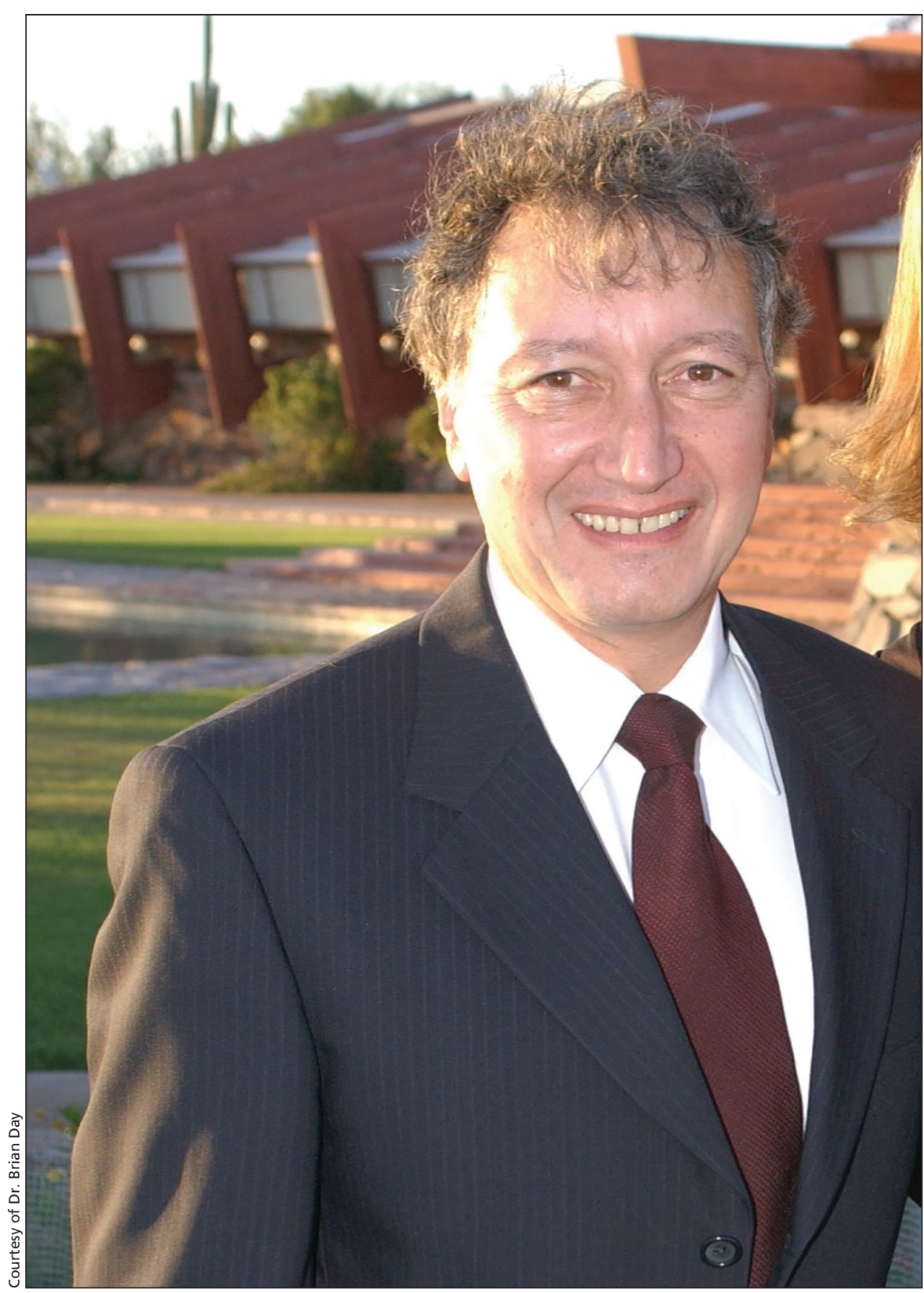

Orthopedic surgeon Dr. Brian Day of Cambie Surgery Centre says provincial laws limiting private care have resulted in rationing and long waiting lists.

blended practices violates Section 7 of the Charter of Rights and Freedoms guaranteeing "right to life, liberty and security of the person," Gall said.

The law also keeps residents from using private insurance to pay for treatment for things covered by the public system, despite the fact that some groups, such as those covered under WorkSafe BC injury claims, get expedited private care. That violates the Charter's equality provisions under Section 15, argued Gall.

The arguments echoed long-held positions of orthopedic surgeon Dr. Brian Day, Cambie's co-founder and 
the visible face of the case. He contends provincial laws limiting private care have resulted in rationing and long waiting lists.

The alleged Charter violations are far from clear cut, said Penner, as he reviewed previous Charter decisions. A key test, for instance, is whether legislation violates the principles of fundamental justice under Section 7. Past rulings have specifically warned against applying it to social policies, he pointed out.

Gall noted that the Supreme Court of Canada's 2005 decision in the Dr. Jacques Chaoulli challenge affirmed Quebecers' right to use private medical insurance to pay for publicly insured services when the public system was inadequate.
But Penner said the wording of the Canadian and Quebec charters differ on fundamental freedoms and only three of nine Supreme Court justices found the Quebec law violated the Canadian Charter in Chaoulli. The evidence in the Cambie case is not the same, he added. "It will tell a very different story."

Even if evidence points to Charter violations, he said, such violations are legal under Section 1 of the Charter, which allows "reasonable limits prescribed by law as can be demonstrably justified in a free and democratic society."

The justification here is government's ability to ensure universal access based on need, not ability to pay, said Penner, adding courts have deferred to legislatures on social policies such as those covering housing.

Granting the plaintiffs' application would reverse that by putting patients with money or insurance ahead of those without, said Penner.

Penner was expected to take two days to present the government's defence, with intervenors on both sides of the case presenting separate arguments later in the week.

The trial is scheduled to last six months and hear from dozens of witnesses, including experts, historians and patients. Steeves' decision is expected to end up being reviewed by the Supreme Court. - Steve Mertl, Vancouver, BC

CMAJ 2016. DOI:10.1503/cmaj.109-5327 